\title{
APLIKASI ERESHA MOBILE BERBASIS ANDROID DENGAN METODE PERSONAL EXTREME PROGRAMMING DI ERA INDUSTRI 4.0
}

\author{
Agus Suharto, Mardiana \\ Program Studi S1 Teknik Informatika, STMIK Eresha \\ Jl. Raya Puspiptek No.11, Buaran, Serpong, Tangerang Selatan, Banten, 15310 \\ dosen40029@eresha.ac.id
}

\begin{abstract}
STMIK Eresha has a facebook group site called "Kabar Eresha", where the site is a means of exchanging information about lectures. However, this information has not been conveyed properly, because the Kabar Eresha group is closed and not all STMIK Eresha students have access to the group's website. This makes information difficult to access and causes students to find out the latest information about lectures. The author makes a smartphone application "Eresha Mobile" using the help of supporting software for Android Studio and Personal Extreme Programming as a method of developing applications. The results achieved in this study are in the form of an android mobile based application with automatic notification every time there is a news update, announcement and lecture activity without access and first login to the Facebook group "Kabar Eresha". The results of the questionnaire with the EUCS method obtained an average score of 3.41087 when measured using the Kaplan theory and Norton entered the rank of satisfied.
\end{abstract}

Keywords: Mobile android, Android Studio, Personal Extreme Programming, EUCS

\begin{abstract}
Abstrak - STMIK Eresha mempunyai situs grup facebook yang bernama "Kabar Eresha", dimana situs tersebut merupakan sarana bertukar informasi seputar perkuliahan. Namun informasi tersebut masih belum tersampaikan dengan baik, dikarenakan grup Kabar Eresha bersifat tertutup dan tidak semua mahasiswa/i STMIK Eresha memiliki akses menuju situs grup tersebut. Hal itu membuat informasi sulit untuk diakses dan menyebabkan mahasiswa/i akan ketinggalan informasi terbaru mengenai perkuliahan. Penulis membuat aplikasi smartphone "Eresha Mobile" menggunakan bantuan perangkat lunak pendukung Android Studio serta Personal Extreme Programming sebagai metode pengembangan aplikasi nya. Hasil yang dicapai pada penelitian ini adalah berupa aplikasi berbasis mobile android dengan notifikasi otomatis setiap ada pembaharuan berita, pengumuman dan kegiatan perkuliahaan tanpa akses dan login dahulu pada group facebook "Kabar Eresha". Hasil kuesioner dengan metode EUCS mendapatkan skor rata rata 3,41087 jika diukur menggunakan teori Kaplan dan Norton masuk pada peringkat puas.
\end{abstract}

Kata Kunci: Aplikasi Mobile, Android Studio, Personal Extreme Programming, EUCS

\section{PENDAHULUAN}

Di zaman teknologi, smartphone menjadi salah satu peran penting dalam kehidupan manusia, apalagi dengan adanya sebuah internet yang semakin memudahkan manusia dalam melakukan segala aktivitas.

STMIK Eresha mempunyai situs grup Facebook, yaitu Kabar Eresha, dimana situs tersebut merupakan sarana bertukar informasi seputar perkuliahan. Namun informasi tersebut masih belum tersampaikan dengan baik, dikarenakan grup Kabar Eresha bersifat tertutup dan tidak semua mahasiswa/i STMIK Eresha memiliki akses menuju situs grup tersebut. Hal itu membuat informasi akan sulit diakses dengan cepat sehingga menyebabkan mahasiswa/i akan ketinggalan informasi terbaru dan lain sebagainya.
Penyampaian informasi di STMIK Eresha hanya dilakukan melalui situs grup Kabar Eresha. Sementara itu, bagi Mahasiswa yang belum memiliki akses menuju situs grup tersebut akan menjadi sulit dalam mengakses informasi dengan cepat. Sehingga, keterlambatan dalam menerima informasi dapat menyebabkan suatu permasalahan tersendiri bagi mahasiswa/i STMIK Eresha. Hal itu menyebabkan informasi belum tersampaikan dengan baik. Mengingat pembahasan pada permasalahan yang begitu luas, maka ruang lingkup ini hanya meliputi proses perancangan aplikasi "Eresha Mobile" sebagai wadah dalam bertukar informasi di STMIK Eresha pada perangkat smart phone

\section{A. Android}

Salah satu sistem operasi dan platform untuk perangkat mobile yang didukung oleh perusahaan 
raksasa Google, dimana setiap versinya menggunakan nama cemilan manis dan diawal namanya terurut alphabet. Sistem operasi ini peningkatan setap versinya berkisar enam hingga sembilan bulan, Rilis utama yang terbaru adalah Android 8.0 "Oreo". Android menyertakan kit development perangkat lunak untuk penulisan kode asli dan perakitan modul perangkat lunak untuk membuat aplikasi bagi pengguna Android. pengembangan aplikasi android ini flatformnya sudah banyak pilihan mulai dari Eclipse, android studio, flutter \& Dart dsb

\section{B. Push Notification}

Push Notification adalah pesan yang muncul di perangkat seluler pengguna. Administrator aplikasi dapat mengirimnya kapan saja, pengguna tidak harus berada dalam saat aplikasi dijalankan untuk menerima notifikasi tersebut. Notifikasi terlihat seperti pesan teks SMS dan peringatan seluler, tetapi hanya menjangkau pengguna yang telah menginstal aplikasi . Setiap platform seluler memiliki dukungan untuk Notifikasi seperti Google Cloud Message (GCM) untuk Android, Apple Push Notification Service (APNs) untuk Ios, , dan Microsoft Push Notification Service (MPNS) untuk Windows Phone Bagaimana cara kerja notifikasi push?

Administrator dalam mengirimkan push notification antara lain:

- Layanan push notification Setiap sistem operasi seluler (OS), termasuk iOS, Android, Fire OS, Windows, dan BlackBerry, memiliki layanannya sendiri.

- Administrator aplikasi. mengaktifkan aplikasinya dengan OSPNS (Operating System Push Notifiation Service) . Kemudian, pengembang aplikasi menguploadnya ke App Store.

- Aplikasi pada klien. yang menginstal aplikasi sesuai dengan OS yang dipasang di perangkat pengguna menerima pemberitahuan masuk.

\section{Personal Extreme Programming (PXP)}

Personal Extreme Programming didasarkan pada asumsi bahwa pengembangan Sistem informasi pada prosesnya sering kali berubah ubah , Dirancang untuk tim yang sedikit dengan waktu tidak panjang .Metode ini adalah bagien dari agile standar . terdapat 7 fase pada pengembangan menggunakan PXP ini .

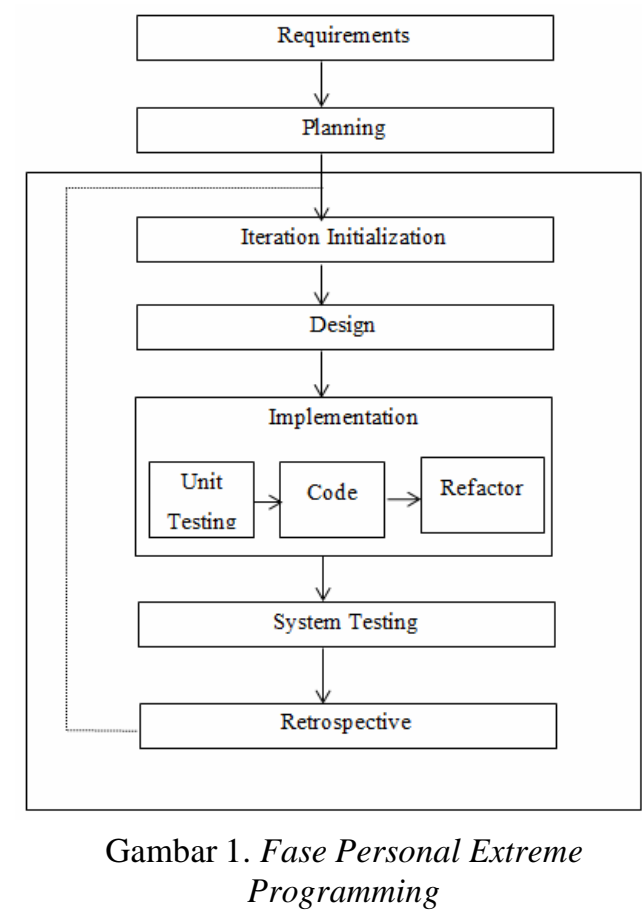

\section{Requirements}

Requirements merupakan fase awal hasil dari identifikasi, dan proses pengumpulan data selanjutnya dianalisa baik kebutuhan sistem, Kebutuhan perangkat keras dan Perangkat lunaknya lalu dilanjutkan dengan pembentukan arsitektur program.

2. Planning

Pada fase Planning di PXP ini adalah merupakan tahapan untuk menentukan skala prioritas dan memutuskan fitur dan fungsionalitas apa yang menjadi nilai maksimum dari proses bisnis suatu pengembangan system informasi

3. Iteration Initialization

Iteration initialization merupakan fase fungsionalitas yang sudah dibentuk dan diputuskan alur bisnis dari tahapan planning lalu dijabarkan dengan penggambaran diagram Bahasa pemodelan standar menggunakan UML dimana diagram yang digunakan adalah Use case, Activity diagram, Sequence diagram Class diagram.

4. Design

Design merupakan fase dimana tahapan ini mulai mendesan mulai desain database dan desain antarmuka pengguna /UI (User Interface.

5. Implementation

Implementation pada fase ini adalah melakukan tahapan pengkodean (Coding) dengan kolaborasi bahasa Java di editor android 
studio dan PHP serta databasenya menggunakan MySQL.

6. Refactoring

Pada fase ini adalah mengkoreksi dan merevisi kode. Ketika kode selesai diuji dalam unit testing, apabila ada kesalahan maka dilakukan koreksi ulang atau refactor pada kesalahan kode ditemukan , apabila tidak ada kesalahan maka dilanjutkan ke unit selanjutnya.

7. System Testing

System Testing merupakan fase dimana ketika fase Implementasi pengkodean selesai dlaksanakan apakah masih ada kekurangan atau sudah berjalan dengan baik. Tahapan pengujian pada penelitian ini menggunakan Black Box Testing.

8. Retrospective

Retrospective adalah fase akhir adalah dimana rapat yang diadakan di akhir iterasi dalam pengembangan perangkat lunak atau menyimpulkan setiap fase yang dilakukan Selama retrospektif, tim merefleksikan apa yang terjadi dalam iterasi dan mengidentifikasi tindakan untuk perbaikan di masa mendatang.

\section{METODE PENELITIAN}

Metode Penelitian dilakukan dengan beberapa tahapan, antara lain:

\section{A. Observasi}

Pengumpulan data observasi, yaitu melihat dan mengunjung langsung ke objek yang terjadi kegiatan Informasi akademik di STMIK Eresha. Pada observasi ini dilakukan untuk mengetahui di lapangan dari tempat penelitian dalam membangun aplikasi smartphone "Eresha Mobile".

\section{B. Wawancara}

Kegiatan ini dilakukan dengan melakukan wawancara terhadap pihak-pihak yang berkaitan dalam perancangan aplikasi smartphone "Eresha Mobile" dengan tujuan mendapatkan informasi yang lebih lengkap di STMIK Eresha.

\section{C.Studi Pustaka}

Studi Pustaka dilakukan untuk mencari data-data pada STMIK Eresha untuk membantu memecahkan masalah dalam penelitian ini.

\section{Metode Pengembangan Sistem}

Metode pengembangan sistem yang digunakan dalam membangun aplikasi "Eresha Mobile",

\section{yaitu Personal Extreme Programming} (PXP).

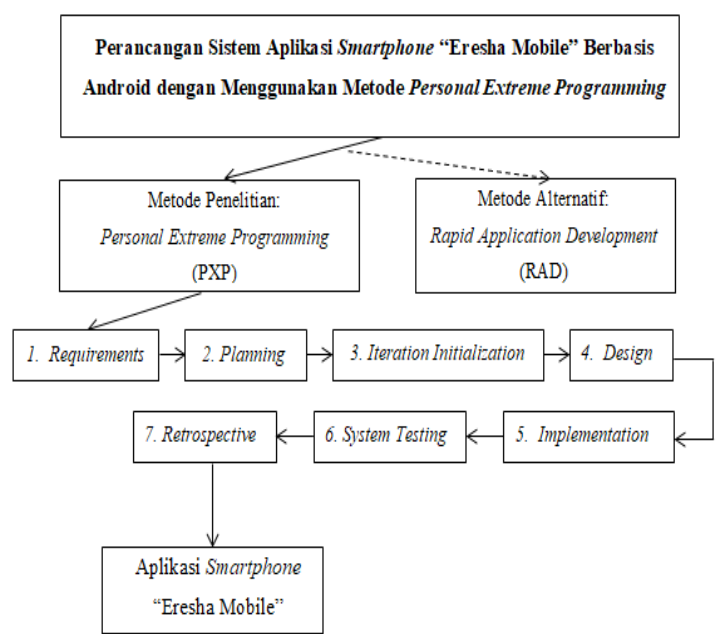

Gambar. 2 Kerangka Pemikiran

\section{HASIL DAN PEMBAHASAN}

Pada Bab Hasil dan pembahasan ini penulis mula menerapkan metode XP tersebut dengan 7 fasenya:

\section{A. REQUIREMENTS}

Kebutuhan perangkat keras (hardware) yang digunakan dalam membangun dan merancang sistem aplikasi "Eresha Mobile", antara lain:

1. Processor Core i3

2. RAM 4 GB

3. Harddisk $500 \mathrm{~GB}$

4. Smartphone Android

Kebutuhan Perangkat Lunak (Software)

Kebutuhan perangkat lunak (software) yang digunakan dalam membangun dan merancang sistem aplikasi "Eresha Mobile", antara lain:

1. Android Studio versi 3.1.1

2. XAMPP versi 7.2.4

3. Notepad++ versi 7.3.3

4. Adobe Photoshop CC 2015

\section{B. PLANNING}

Spesifikasi kebutuhan dari sistem aplikasi "Eresha Mobile", yaitu: 
1. User dari aplikasi "Eresha Mobile", yaitu staff dan mahasiswa. Staff bertugas sebagai admin yang akan mengelola informasi. Mahasiswa akan menerima informasi dengan mengakses aplikasi tersebut.

2. Informasi yang akan diberikan merupakan informasi seputar perkuliahan dan segala bentuk aktivitas lainnya yang terjadi di lingkungan STMIK Eresha.

\section{ITERATION INITIALIZATION}

Iteration initialization pada fase ini merupakan fungsionalitas yang sudah dibentuk dan diputuskan alur bisnis dari tahapan planning diagram Bahasa pemodelan standar menggunakan UML yaitu :

\section{Use Case Diagram Admin}

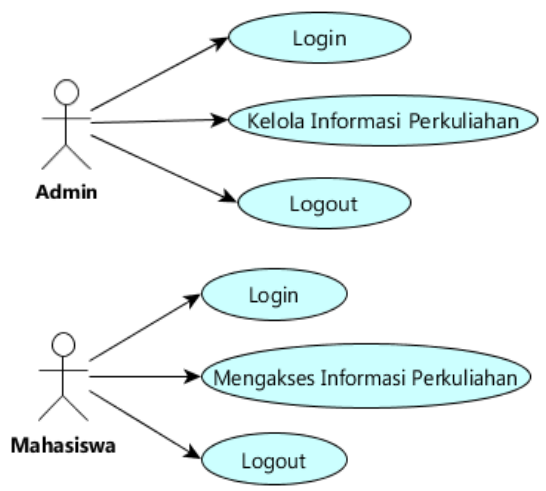

Gambar 3. Use Case Diagram Admin dan Mahasiswa

Setelah diagram use case dibuat agar dapat melengkapi saat pengkodingan nantinya maka selanjutnya adalah pembuatan class diagram dengan atribut dan method nya seperti gambar dibawah ini :

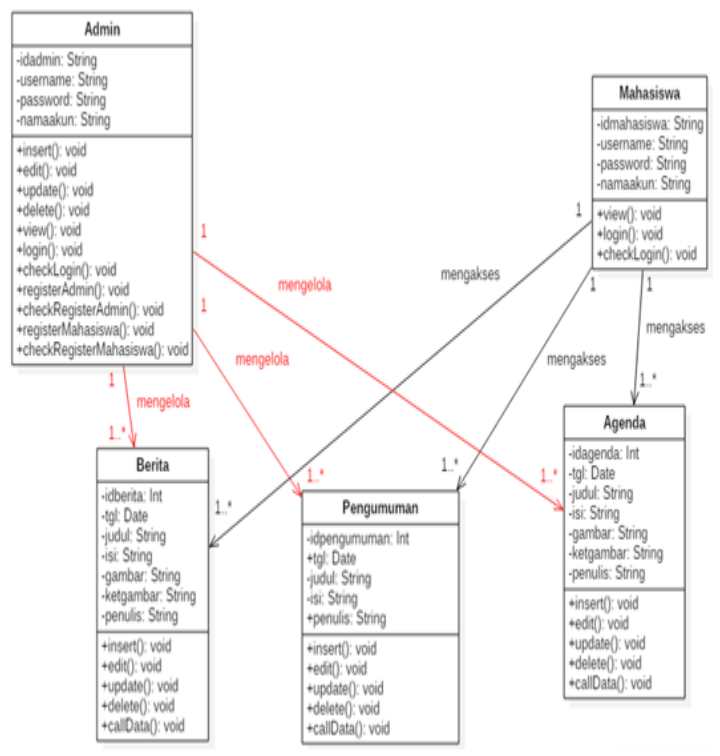

Gambar 4. Class Diagram

2. Activity Diagram Admin
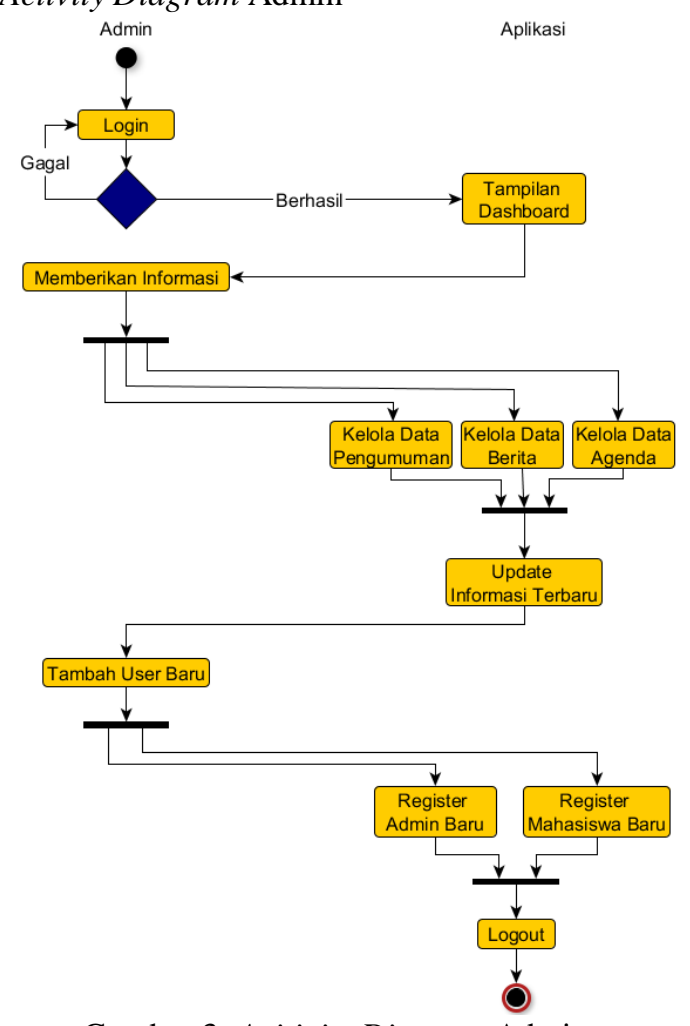

Gambar 3. Acitivity Diagram Admin

3. Activity Diagram Mahasiswa

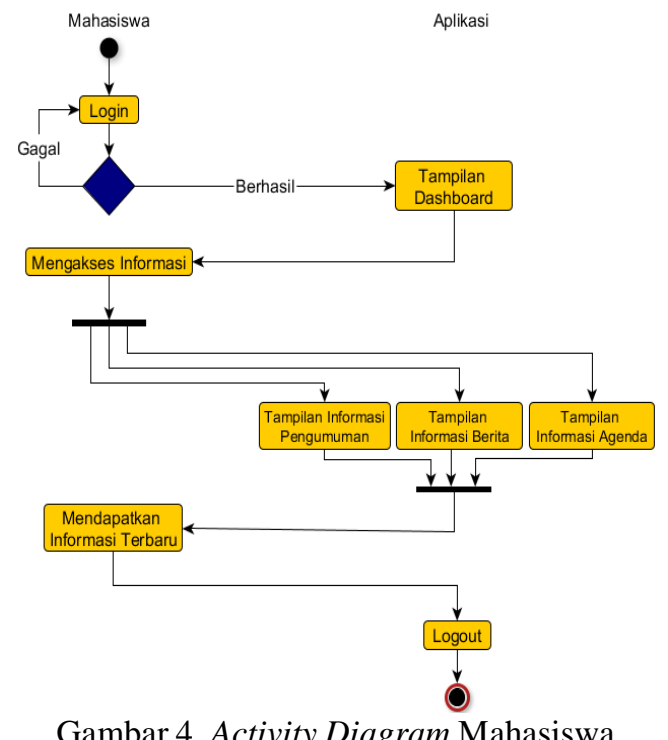

Gambar 4. Activity Diagram Mahasiswa

\section{DESIGN}

Pada tahap desain perancangan "Eresha Mobile" ini terdiri dari perancangan antar muka dan desain databasenya dimana terdiri dari 5 tabel, yaitu tabel admin, tabel mahasiswa, tabel berita, tabel agenda dan tabel pengumuman. 
Tabel 1

Tabel admin

\begin{tabular}{|c|c|c|c|}
\hline Field Name & $\begin{array}{c}\text { Data } \\
\text { Type }\end{array}$ & $\begin{array}{c}\text { Field } \\
\text { Size }\end{array}$ & Description \\
\hline idadmin & Char & 10 & $\begin{array}{c}\text { Primary } \\
\text { Key }\end{array}$ \\
\hline username & Varchar & 25 & \\
\hline password & Varchar & 15 & \\
\hline namaakun & Varchar & 25 & \\
\hline
\end{tabular}

Tabel 2

\begin{tabular}{|l|l|l|l|}
\hline Field Name & $\begin{array}{l}\text { Data } \\
\text { Type }\end{array}$ & $\begin{array}{l}\text { Field } \\
\text { Size }\end{array}$ & Description \\
\hline idmahasiswa & Char & 10 & $\begin{array}{l}\text { Primary } \\
\text { Key }\end{array}$ \\
\hline username & varchar & 25 & \\
\hline password & varchar & 15 & \\
\hline namaakun & varchar & 25 & \\
\hline
\end{tabular}

Tabel Mahasiswa

Tabel 3

Tabel Berita

\begin{tabular}{|l|l|l|l|}
\hline Field Name & $\begin{array}{l}\text { Data } \\
\text { Type }\end{array}$ & $\begin{array}{l}\text { Field } \\
\text { Size }\end{array}$ & Description \\
\hline idberita & Int & 10 & $\begin{array}{l}\text { Primary } \\
\text { Key }\end{array}$ \\
\hline tgl & Date & & \\
\hline judul & varchar & 255 & \\
\hline isi & Teks & & \\
\hline gambar & Teks & & \\
\hline ketgambar & varchar & 255 & \\
\hline penulis & varchar & 25 & \\
\hline
\end{tabular}

Tabel 4

Tabel Agenda.

\begin{tabular}{|c|c|c|c|}
\hline Field Name & $\begin{array}{c}\text { Data } \\
\text { Type }\end{array}$ & $\begin{array}{c}\text { Field } \\
\text { Size }\end{array}$ & Description \\
\hline idagenda & int & 10 & $\begin{array}{c}\text { Primary } \\
\text { Key }\end{array}$ \\
\hline tgl & date & & \\
\hline judul & varchar & 255 & \\
\hline Isi & teks & & \\
\hline Gambar & teks & & \\
\hline Ketgambar & varchar & 255 & \\
\hline Penulis & varchar & 25 & \\
\hline
\end{tabular}

\begin{tabular}{|c|c|c|c|}
\hline Field Name & $\begin{array}{c}\text { Data } \\
\text { Type }\end{array}$ & $\begin{array}{c}\text { Field } \\
\text { Size }\end{array}$ & Description \\
\hline idpengumuman & char & 10 & $\begin{array}{c}\text { Primary } \\
\text { Key }\end{array}$ \\
\hline tgl & date & & \\
\hline judul & varchar & 255 & \\
\hline isi & teks & & \\
\hline penulis & varchar & 25 & \\
\multicolumn{4}{|c|}{ Tabel Pengumuman } \\
Tabel 5
\end{tabular}

\section{E. IMPLEMENTATION}

1. Halaman Login

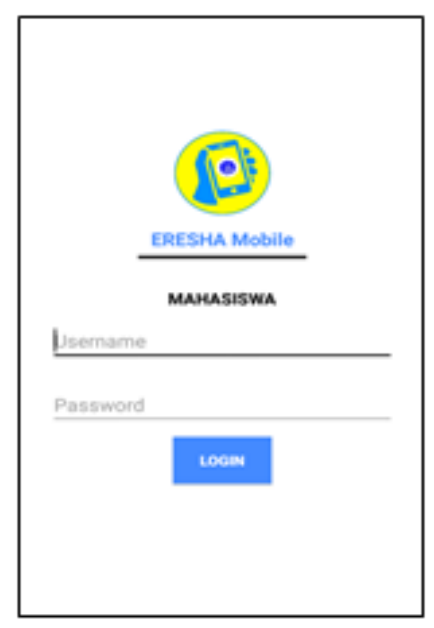

Gambar 5. Halaman Login

2. Halaman Profil

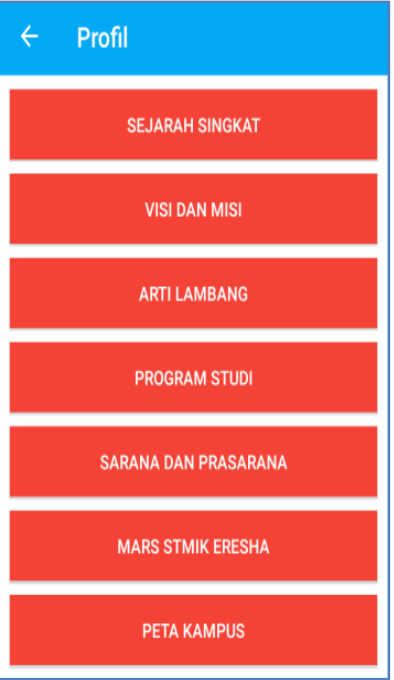

Gambar 6. Halaman Profil 


\section{Halaman Berita}

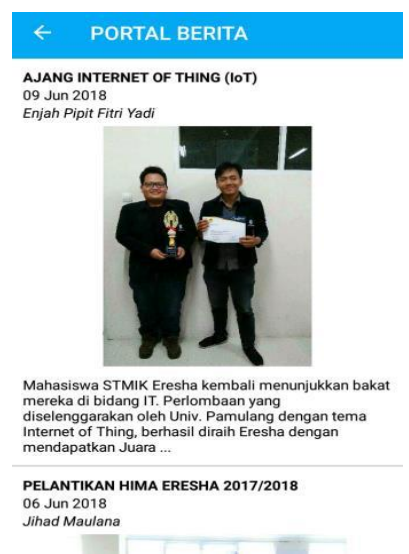

Gambar 7. Halaman Berita

4. Halaman Insert Berita

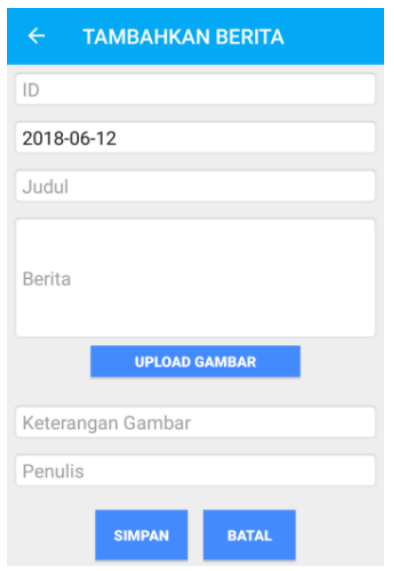

Gambar 7. Halaman Insert Berita

\section{Halaman Edit dan Delete Berita}

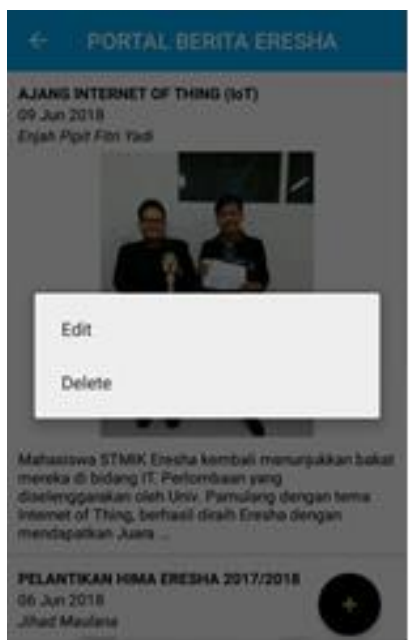

Gambar 8.. Halaman Edit dan Delete Berita
6. Halaman Update Berita

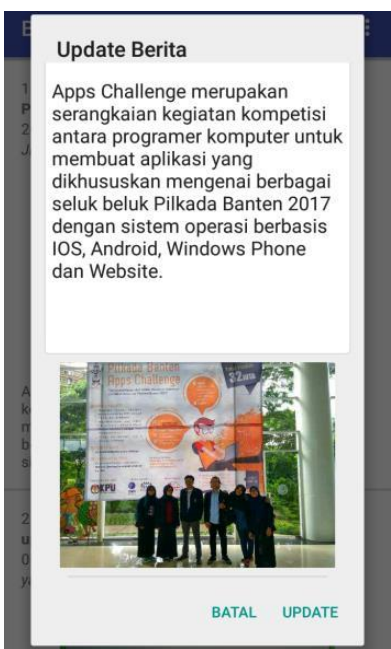

Gambar 9. Halaman Update Berita

7. Halaman Agenda

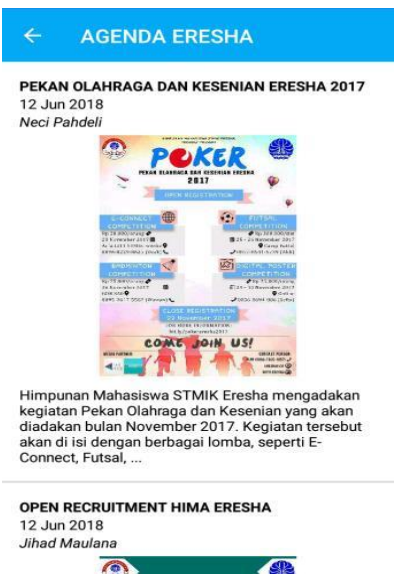

Gambar 10. Halaman Agenda

\section{Halaman Pengumuman}

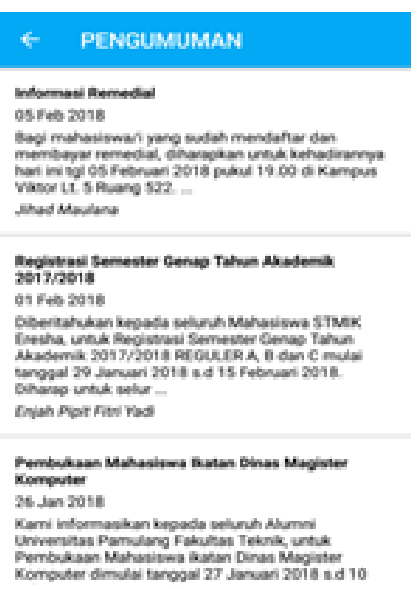

Gambar 11. Halaman Pengumuman 
Gambar 14. Halaman Notifikasi

\section{Halaman Register}

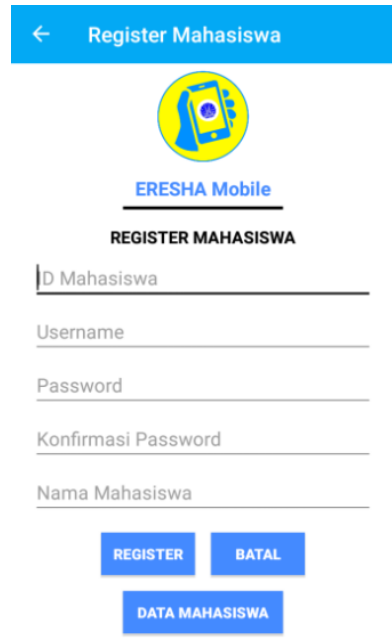

Gambar 12. Halaman Register

10. Halaman Kontak Kami



Gambar 13. Halaman Kontak Kami

\section{Halaman Notifikasi}

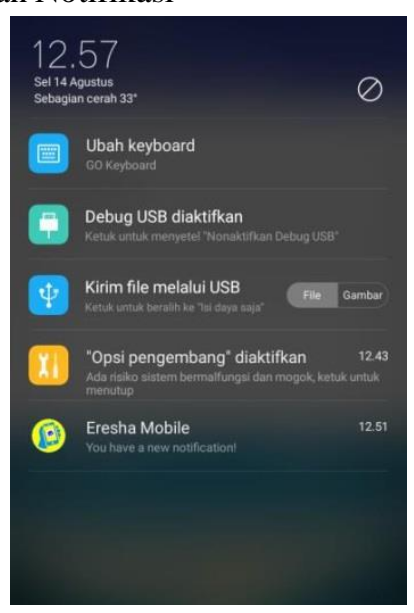

12. Halaman Tentang Aplikasi

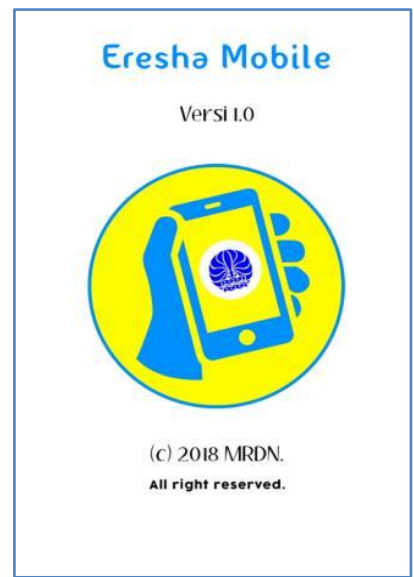

Gambar 15. Halaman Tentang Aplikasi

\section{System Testing}

Pada tahap System Testing adalah ujicoba dari aplikasi yang sedang dibuat, penggunaan ujicoba menggunakan metode blackbox

Tabel 6. Uji coba sistem

\begin{tabular}{|c|c|c|c|c|}
\hline No. & Uji Tes & Deskripsi & Harapan & Hasil \\
\hline 1 & $\begin{array}{c}\text { Login } \\
\text { User }\end{array}$ & $\begin{array}{c}\text { User } \\
\text { memasukkan } \\
\text { username dan } \\
\text { password pada } \\
\text { form Login } \\
\text {. }\end{array}$ & $\begin{array}{c}\text { Sistem akan } \\
\text { memvalidasi } \\
\text { data. Jika } \\
\text { berhasil, } \\
\text { maka akan } \\
\text { masuk ke } \\
\text { Menu } \\
\text { Dashboard. } \\
\text { Jika gagal, } \\
\text { maka akan } \\
\text { mengulang. } \\
\end{array}$ & Berhasil \\
\hline 2 & $\begin{array}{l}\text { Login } \\
\text { User }\end{array}$ & $\begin{array}{c}\text { User } \\
\text { memasukkan } \\
\text { username dan } \\
\text { password pada } \\
\text { form Login } \\
\text { dengan } \\
\text { character } \\
\text { symbol dan } \\
\text { tanda baca } \\
\text {. }\end{array}$ & $\begin{array}{c}\text { Sistem akan } \\
\text { memvalidasi } \\
\text { data. }\end{array}$ & $\begin{array}{c}\text { Tidak } \\
\text { berhasil } \\
\\
\text { (Penangan } \\
\text { an: } \\
\text { Memvalida } \\
\text { si isian } \\
\text { dengan } \\
\text { batasan } \\
\text { kode ascii) }\end{array}$ \\
\hline 2 & $\begin{array}{l}\text { Menam } \\
\text { pilkan } \\
\text { Halama } \\
\text { n Berita/ } \\
\text { Agenda/ } \\
\text { Pengum } \\
\text { uman }\end{array}$ & $\begin{array}{c}\text { User klik } \\
\text { ImageButton } \\
\text { Berita/Agenda/ } \\
\text { Pengumuman } \\
\text { pada Menu } \\
\text { Dashboard } \\
\text { untuk pindah ke } \\
\text { Halaman } \\
\text { Berita/Agenda/ } \\
\text { Pengumuman. }\end{array}$ & $\begin{array}{c}\text { Sistem akan } \\
\text { menampilkan } \\
\text { list Berita/ } \\
\text { Agenda/ } \\
\text { Pengumuman } \\
\text {. }\end{array}$ & Berhasil \\
\hline 3 & $\begin{array}{c}\text { Insert } \\
\text { Informa } \\
\text { si } \\
\text { Berita/ } \\
\text { Agenda/ } \\
\text { Pengum } \\
\text { uman }\end{array}$ & $\begin{array}{c}\text { Admin klik } \\
\text { Button tanda } \\
(+) \text { pada } \\
\text { halaman } \\
\text { Berita/Agenda/ } \\
\text { Pengumuman } \\
\text { untuk } \\
\text { menambahkan } \\
\text { informasi } \\
\text { terbaru. } \\
\text { Kemudian } \\
\text { Admin } \\
\text { menginput }\end{array}$ & $\begin{array}{c}\text { Sistem akan } \\
\text { menyimpan } \\
\text { data ke } \\
\text { database dan } \\
\text { menampilkan } \\
\text { notifikasi } \\
\text { informasi } \\
\text { terbaru. }\end{array}$ & Berhasil \\
\hline
\end{tabular}




\begin{tabular}{|c|c|c|c|c|}
\hline No. & Uji Tes & Deskripsi & Harapan & Hasil \\
\hline & & $\begin{array}{l}\text { informasi yang } \\
\text { tertera pada } \\
\text { halaman Insert } \\
\text { Berita/Agenda/ } \\
\text { Pengumuman. }\end{array}$ & & \\
\hline 4 & $\begin{array}{c}\text { Edit dan } \\
\text { Update } \\
\text { Informa } \\
\text { si } \\
\text { Berita/ } \\
\text { Agenda/ } \\
\text { Pengum } \\
\text { uman }\end{array}$ & $\begin{array}{l}\text { Admin klik } \\
\text { Button Edit } \\
\text { pada salah satu } \\
\text { list di halaman } \\
\text { Berita/Agenda/ } \\
\text { Pengumuman } \\
\text { yang ingin } \\
\text { diedit. } \\
\text { Kemudian } \\
\text { Admin } \\
\text { mengubah } \\
\text { informasi yang } \\
\text { tertera pada } \\
\text { halaman } \\
\text { Update } \\
\text { Berita/Agenda/ } \\
\text { Pengumuman. }\end{array}$ & $\begin{array}{l}\text { Sistem akan } \\
\text { mengupdate } \\
\text { perubahan } \\
\text { data, baik } \\
\text { pada sistem } \\
\text { maupun } \\
\text { database. }\end{array}$ & Berhasil \\
\hline 5 & $\begin{array}{c}\text { Delete } \\
\text { Informa } \\
\text { si } \\
\text { Berita/ } \\
\text { Agenda/ } \\
\text { Pengum } \\
\text { uman }\end{array}$ & $\begin{array}{l}\text { Admin klik } \\
\text { Button Delete } \\
\text { pada salah satu } \\
\text { list di halaman } \\
\text { Berita/Agenda/ } \\
\text { Pengumuman } \\
\text { yang ingin } \\
\text { diedit. } \\
\text { Kemudian } \\
\text { sistem akan } \\
\text { menghapus } \\
\text { informasi } \\
\text { tersebut. }\end{array}$ & $\begin{array}{l}\text { Sistem akan } \\
\text { menghapus } \\
\text { informasi, } \\
\text { baik pada } \\
\text { sistem } \\
\text { maupun } \\
\text { database. }\end{array}$ & Berhasil \\
\hline 6 & $\begin{array}{l}\text { Register } \\
\text { Account }\end{array}$ & $\begin{array}{lr}\text { Admin } & \text { klik } \\
\text { Button Register } \\
\text { Admin/Mahasis } \\
\text { wa pada } \\
\text { halaman } \\
\text { Setelan untuk } \\
\text { menambahkan } \\
\text { akun baru. } \\
\text { Kemudian } \\
\text { Admin } \\
\text { menginput } \\
\text { informasi yang } \\
\text { tertera pada } \\
\text { halaman } \\
\text { Register } \\
\text { tersebut. }\end{array}$ & $\begin{array}{c}\text { Sistem akan } \\
\text { menyimpan } \\
\text { data ke } \\
\text { database. }\end{array}$ & Berhasil \\
\hline 7 & $\begin{array}{l}\text { Menam } \\
\text { pilkan } \\
\text { Informa } \\
\text { si Profil } \\
\text { STMIK } \\
\text { Eresha }\end{array}$ & $\begin{array}{l}\text { Mahasiswa klik } \\
\text { ImageButton } \\
\text { Profil pada } \\
\text { Menu } \\
\text { Dashboard. } \\
\text { Kemudian } \\
\text { sistem akan } \\
\text { menampilkan } \\
\text { Button, seperti } \\
\text { Sejarah Singkat, } \\
\text { Visi dan Misi, } \\
\text { Program Studi } \\
\text { dan sebagainya. } \\
\text { Ketika } \\
\text { Mahasiswa } \\
\text { mengklik salah } \\
\text { satu button } \\
\text { tersebut, maka } \\
\text { sistem akan } \\
\text { menampilkan } \\
\text { informasi yang } \\
\text { tertera. }\end{array}$ & $\begin{array}{c}\text { Sistem akan } \\
\text { menampilkan } \\
\text { informasi- } \\
\text { informasi } \\
\text { dari profil } \\
\text { STMIK } \\
\text { Eresha. }\end{array}$ & Berhasil \\
\hline 8 & $\begin{array}{c}\text { Menam } \\
\text { pilkan } \\
\text { Halama } \\
\text { n } \\
\text { Hubungi } \\
\text { Kami }\end{array}$ & $\begin{array}{c}\text { Mahasiswa klik } \\
\text { Button Hubungi } \\
\text { Kami. } \\
\text { Kemudian } \\
\text { sistem akan } \\
\text { menampilkan } \\
\text { halaman form } \\
\text { yang bertujuan } \\
\text { agar Mahasiswa } \\
\text { bisa mengirim } \\
\text { kritik dan saran } \\
\end{array}$ & $\begin{array}{c}\text { Sistem akan } \\
\text { menampilkan } \\
\text { halaman } \\
\text { form } \\
\text { Hubungi } \\
\text { Kami dan } \\
\text { ketika } \\
\text { Mahasiswa } \\
\text { mengisi form } \\
\text { tersebut, data } \\
\text { akan } \\
\end{array}$ & Berhasil \\
\hline
\end{tabular}

\begin{tabular}{|c|c|c|c|c|}
\hline No. & Uji Tes & Deskripsi & Harapan & Hasil \\
\hline & & $\begin{array}{c}\text { atau } \\
\text { menanyakan } \\
\text { informasi } \\
\text { lainnya. }\end{array}$ & $\begin{array}{l}\text { tersimpan di } \\
\text { google doc. }\end{array}$ & \\
\hline 9 & $\begin{array}{c}\text { Menam } \\
\text { pilkan } \\
\text { Halama } \\
\text { n } \\
\text { Faceboo } \\
\text { k Kabar } \\
\text { Eresha }\end{array}$ & $\begin{array}{c}\text { Mahasiswa } \\
\text { mengklik } \\
\text { Button } \\
\text { Kunjungi } \\
\text { Facebook } \\
\text { Kami. } \\
\text { Kemudian } \\
\text { sistem akan } \\
\text { men-direct link } \\
\text { ke halaman } \\
\text { Facebook } \\
\text { Kabar Eresha. }\end{array}$ & $\begin{array}{c}\text { Sistem akan } \\
\text { menampilkan } \\
\text { halaman } \\
\text { Facebook } \\
\text { Kabar } \\
\text { Eresha. }\end{array}$ & Berhasil \\
\hline 10 & $\begin{array}{c}\text { Menam } \\
\text { pilkan } \\
\text { Halama } \\
\text { n } \\
\text { Website } \\
\text { my.eres } \\
\text { ha.ac.id }\end{array}$ & $\begin{array}{c}\text { Mahasiswa klik } \\
\text { Button } \\
\text { Kunjungi } \\
\text { Website Kami. } \\
\text { Kemudian } \\
\text { sistem akan } \\
\text { men-direct link } \\
\text { ke halaman } \\
\text { Website } \\
\text { my.eresha.ac.id. }\end{array}$ & $\begin{array}{c}\text { Sistem akan } \\
\text { menampilkan } \\
\text { halaman } \\
\text { Website } \\
\text { my.eresha.ac. } \\
\text { id. }\end{array}$ & Berhasil \\
\hline 11 & $\begin{array}{c}\text { Menam } \\
\text { pilkan } \\
\text { Halama } \\
\text { n } \\
\text { Tentang } \\
\text { Aplikasi }\end{array}$ & $\begin{array}{c}\text { Mahasiswa klik } \\
\text { Button Tentang } \\
\text { Aplikasi. } \\
\text { Kemudian } \\
\text { sistem akan } \\
\text { menampilkan } \\
\text { halaman } \\
\text { Tentang } \\
\text { Aplikasi. }\end{array}$ & $\begin{array}{c}\text { Sistem akan } \\
\text { menampilkan } \\
\text { halaman } \\
\text { Tentang } \\
\text { Aplikasi. }\end{array}$ & Berhasil \\
\hline
\end{tabular}

\section{RETROSPECTIVE}

Pada tahap ini adalah kesimpulan dari semua tahapan PXP apakah telah sesuai solusi yang diharapkan dari pembuatan aplikasi "Eresha Mobile".

\section{Metode EUCS}

Untuk kesesuaian aplikasi menggunakan metode kuesioner EUCS (End User Computing Satisfaction) mencakup 5 komponen yang terdri dari Content,Accurary, Format, Ease of use dan Timeliness, lalu instrument penilaian menggunakan skala likert 1 sampai 5 . Pemberian skor seperti tabel dibawah ini :

Tabel 7. Skala Likert

\begin{tabular}{|l|l|c|}
\hline Skor & Keterangan & Singkatan \\
\hline 1 & Sangat Tidak Puas & STP \\
\hline 2 & Tidak Puas & TP \\
\hline 3 & Ragu Ragu & RR \\
\hline 4 & Puas & P \\
\hline 5 & Sangat Puas & SP \\
\hline
\end{tabular}

\section{Responden}

Pemilihan responden yaitu mahasiswa STMIK Eresha angkatan 2017 sebagai end user pemakai aplikasi. Prodi yang diambil dari pangkalan data dikti jumlah responden nya adalah : 
Tabel 8. Jumlah responden

\begin{tabular}{|l|l|l|c|}
\hline No & \multicolumn{1}{|c|}{ Prodi } & Jenjang & Jml Mhs \\
\hline 1 & Teknik Informatika & S2 & 244 \\
\hline 2 & Teknik Informatika & S1 & 776 \\
\hline 3 & Sistem Informasi & S1 & 171 \\
\hline \multicolumn{3}{|c|}{ Total } & $\mathbf{1 1 7 0}$ \\
\hline
\end{tabular}

3. Sampel

Untuk penentuan jumlah sampel setelah jumlah responden didapat adalah menggunakan rumus Slovin :

$$
\mathrm{n}=\frac{\mathrm{N}}{\mathrm{N} \cdot \mathrm{d}^{2}+1}
$$

$\mathrm{n}=$ Sample, $\mathrm{N}=$ Jumlah Responden

$\mathrm{n}=\underline{1170}$

$$
1170 \times 0.1^{2}+1
$$

$\mathrm{n}=92,1131($ pembulatan 92$)$

Hasil jumlah sampel per prodi seperti tabel dibawah ini :

Tabel 9. Persentase Sampel Mahasiswa

\begin{tabular}{|l|c|c|}
\hline Prodi & $(\%)$ & Jumlah Sampel \\
\hline TI -S2 & 21 & 19 \\
\hline TI -S1 & 65 & 60 \\
\hline SI -S1 & 14 & 13 \\
\hline Total & 100 & 92 \\
\hline
\end{tabular}

4. Teori Kaplan dan Norton

Untuk mengukur tingkat kepuasan menggunakan teori Kaplan dan Norton dimana indikatornya adalah sebagai berikut :
1. $4.2 \mathrm{~s} / \mathrm{d} 5=$ Sangat Puas
2. $3.4 \mathrm{~s} / \mathrm{d} 4.1=$ Puas
3. $2.6 \mathrm{~s} / \mathrm{d} 3.3=$ Ragu Ragu
4. $1.8 \mathrm{~s} / \mathrm{d} 2.5=$ Tidak Puas
5. 1 - s/d $1.7=$ Sangat tidak Puas

5. Hasil sebaran EUCS

Hasil dari sebaran kuesioner EUCS terhadap 92 sampel seperti pada tabel berikut :

Tabel 10. Hasil dari sebaran kuesioner EUCS

\begin{tabular}{|l|c|c|c|c|c|}
\hline EUCS & $\mathbf{S P}(\mathbf{5})$ & $\mathbf{P}(\mathbf{4})$ & $\mathbf{R R}(\mathbf{3})$ & $\mathbf{T P}(\mathbf{2})$ & $\mathbf{S T P}(\mathbf{1})$ \\
\hline Content & 25 & 25 & 20 & 5 & 17 \\
\hline Accuracy & 22 & 35 & 25 & 5 & 5 \\
\hline Format & 37 & 30 & 5 & 15 & 5 \\
\hline $\begin{array}{l}\text { Ease of } \\
\text { Use }\end{array}$ & 20 & 27 & 8 & 16 & 20 \\
\hline Timeliness & 21 & 16 & 15 & 20 & 20 \\
\hline Total & $\mathbf{1 2 5}$ & $\mathbf{1 3 3}$ & $\mathbf{7 3}$ & $\mathbf{6 1}$ & $\mathbf{6 7}$ \\
\hline
\end{tabular}

Hasil dari penyebaran di rata rata kan tingkat kepuasan nya menggunakan rumus :

$$
\text { RK }=\frac{\text { JSK }}{\text { JK }}
$$

Sumber :wibowo (2005,p/79)

RK = Rata- rataKepuasan

JSK= Jumlah Skor Kuesioner

$\mathrm{JK}=$ Jumlah Kuesioner

$R K=\frac{(5 \times 125)+(4 \times 133)+(3 \times 73)+(2 \times 61)+(1 \times 67)}{460}$
$R K=\quad \frac{1569}{460}$

\section{$\mathrm{RK}=\mathbf{3 , 4 1 0 8 7}$}

Maka hasil RK 3,41087 berdasarkan teori Kaplan dan norton masuk kategori Puas, sedikit diatas ragu ragu. Sehingga hasil retrospective untuk tahapan PXP tidak perlu di ulang.

\section{KESIMPULAN}

1. Dari hasil penelitian dalam perancangan aplikasi "Eresha Mobile", dengan metode PXP mendapatkan sistem aplikasi berbasis android sesuai kebutuhan pengguna dengan notifikasi setiap ada pembaharuan berita, pengumuman serta info info kegiatan akademik lainnya. Sehingga mahasiswa dan sivitas akademik tidak perlu akses \& login terlebih dahulu ke group "Kabar Eresha".

2. Dari hasil penelitian dengan kuesioner metode EUCS mendapatkan skor Rata rata 3,41087, angka skor ini jika diukur menggunakan teori Kaplan dan Norton pada peringkat Puas, sedikit diatas ragu ragu

Saran yang diberikan untuk pengembangan selanjutnya

1. Pengembangan kedepan sistem aplikasi bisa berjalan berbasis platform lainnya, seperti iPhone.

2. Pengembangan sistem aplikasi dengan metode pengembangan yang berbeda misalnya dengan metode Scrum.

\section{DAFTAR PUSTAKA}

[1]. Sunyoto, andi, Utami Ema dan Ariaji, Tristanto, "Evaluasi Sistem Informasi Yang Dikembangkan Dengan Metodologi Extreme Programming", J.DASI, vol 15 No.2, pp 53-62, Des 2014.

[2]. A.A. Subhan, "Rancang Bangun Sistem Informasi Administrasi Hotel Dengan Metode Extreme Programming", J.Dispotek. vol 8 No. 2, pp. 26-41, Jul. 2017 
[3]. Setiawan Widyadi, Sri Andriati , Asri, "Alternatif Penggunaan Model Pendekatan Agile pada Perancangan Sistem Informasi PKL Online", J.MATRIX, vol 5 No. 3, pp. 122, Feb 2017.

[4]. Dwi Dhani dan Fatony, Ahmad , "Rancang Bangun Sistem Extreme Programming Sebagai Metodologi Pengembangan Sistem", J.Prosisko, vol 3 No. 1, pp 17-20, mar 2016.

[5]. Rahim, Abdul., "Perancangan Aplikasi E Informasi dan Jadwal Perkuliahan Berbasis Mobile Android", J.Processor, vol 12 No 1. , pp. 1000-1010, April 2017.

[6]. Suhatman, Rahmat, Sari, Rika Perdana dan Rahmi, Raisya, ",Pendekatan Metodologi Extreme Programming (XP) pada Aplikasi E-Commerce (Studi Kasus: Sistem Informasi Penjualan Alat Telekomunikasi)",J.Komputer Terapan, vol 2 no. 2 , pp 83-92, nov 2016.

[7]. Kurniawan Henry dan Sandika, Tri "Rancang Bangun Sistem Informasi Kualitas Air Wilayah Sungai di Provinsi Lampung dengan Metode Personal Extreme Programming", J.Ilmiah Esai, vol 8 no. 2, April 2014.

[8]. Saepudin, Isep, Mahardhika , Fajar dan Yahya Samsuri, "Implementasi Metode Extreme Programming pada Aplikasi Biro Jodoh Syari'ah Berbasis Mobile Android", J.JTera, vol 4 no. 1, pp. 37- 40, juni 2019.

[9]. Widiastuti , Fitri Puji dan Suharto, Agus, "Sistem Informasi Dokumentasi Akreditasi dengan Metode Personal Extreme Programming (Studi Kasus Stmik Eresha)", J.Esit, vol 14 no 1, pp. 41-49, April 2019.

[10]. Google Developer Training Team., (2017,Jan 14), Android Developer Fundamental Course.available https://developer.android.com/courses/fund amentals-training/toc-v2.

[11]. Suharto, Agus,"Analisa Evaluasi Sistem Informasi Manajemen Akademik dengan metode PIECES Studi Kasus pada STMIK Eresha", vol 13 no 2, pp 37-46, Oktober 2018 